\title{
RHYNS syndrome
}

INSERM

\section{Source}

INSERM. (1999). Orphanet: an online rare disease and orphan drug data base. RHYNS

syndrome. ORPHA:140976

RHYNS syndrome is characterised by the association of retinitis pigmentosa,

hypopituitarism, nephronophthisis, and skeletal dysplasia. 